\title{
RANCANG BANGUN SISTEM INFORMASI PERPUSTAKAAN SMAN 1 BAYAN BERBASIS WEBSITE DENGAN PHP MYSQL
}

\author{
(Development of Library Information System SMAN 1 BAYAN Based on Website \\ with PHP MYSQL)
}

\author{
Mely Handayani ${ }^{[1]}$, Ahmad Zafrullah Mardiansyah ${ }^{[1]}$ Jatradi $^{[2]}$ \\ ${ }^{[1]}$ Dept. Informatics Engineering, University of Mataram \\ J1. Majapahit 62, Mataram, Lombok NTB, INDONESIA \\ ${ }^{[2]}$ SMAN 1 Bayan, Lombok Utara, NTB, Indonesia \\ Jl. Raya Bayan, Anyar, Bayan, Kabupaten Lombok Utara, NTB, Indonesia \\ Email: melyhandayanind@gmail.com, zaf@unram.ac.id, jatradi@gmail.com
}

\begin{abstract}
Abstrak
Perkembangan ilmu dan teknologi mendorong berkembangnya sistem informasi berbasis website. Hal tersebut juga merambah ke dalam pengelolaan sistem perpustakaan. Peningkatan profesionalisme dan kualitas serta pelayanan yang ditawarkan suatu lembaga merupakan salah satu daya tarik yang menjadi perhatian seksama yang dapat membantu lembaga dalam mengolah data serta menyajikan sebuah informasi yang berkualitas. Pada perpustakaan sekolah SMAN 1 BAYAN proses peminjaman buku yang semula dilakukan secara manual sekarang dapat dilakukan secara komputerisasi. Dengan begitu proses peminjaman dapat dilakukan dengan mudah, cepat dan efisien. Laporan data peminjaman buku awalnya masih bersifat manual yakni dengan cara melakukan rekapitulasi dari proses transaksi peminjaman buku yang terjadi, setelah adanya sistem informasi perpustakaan SMAN 1 BAYAN berbasis website dengan PHP MYSQL proses pembuatan laporan peminjaman buku dapat dilakukan dengan mudah. Dengan adanya sistem informasi ini dapat mempermudah proses pengembalian dan peminjaman buku serta dapat menghasilkan laporan data buku dan data peminjaman yang lebih cepat dan akurat. Setelah dilakukan pengimplementasian sistem ini, selanjutnya dilakukan pengujian sistem. Pengujian dengan menggunakan kuesioner kemudian didapatkan persentase hasil jawaban sangat setuju sebesar $72 \%$ dan setuju sebesar 28\%. Jadi, Berdasarkan persentase hasil pengujian sistem tersebut responden setuju dengan sistem ini, serta sistem ini juga sudah terimplementasi dengan baik.
\end{abstract}

Keywords: Sistem Informasi, Perpustakaan, Website, PHP, MYSQL.

\section{PENDAHULUAN}

Teknologi informasi merupakan salah satu teknologi yang sedang berkembang pesat pada saat ini. Dengan memanfaatkan kemajuan teknologi informasi, pengaksesan terhadap data atau informasi yang tersedia dapat berlangsung secara cepat, efisien serta akurat. Perkembangan ilmu dan teknologi mendorong berkembangnya administrasi berbasis teknologi informasi. Hal tersebut juga merambah ke dalam pengelolaan sistem perpustakaan. Peningkatan profesionalisme dan kualitas serta pelayanan yang ditawarkan suatu lembaga merupakan salah satu daya tarik yang menjadi perhatian seksama sebagai salah satu kriteria bentuk pelayanan yang dapat membantu lembaga dalam mengolah data serta menyajikan sebuah informasi yang berkualitas[1].

Setiap instansi baik itu instansi pemerintah maupun swasta pasti membutuhkan sistem informasi yang dapat menunjang kinerjanya, sehingga mampu mendapatkan, mengolah serta menghasilkan informasi dengan cara yang lebih efektif dan efisien. Sekolah SMAN 1 BAYAN di kecamatan Bayan, Kabupaten Lombok Utara, Provinsi Nusa Tenggara Barat ini merupakan salah satu instansi pemerintah yang telah memanfaatkan teknologi informasi dalam menunjang aktivitas kerjanya. Meskipun beberapa proses manajemennya sudah memanfaatkan teknologi informasi, namun masih ada beberapa aktivitas kerjanya yang belum memanfaatkan teknologi informasi. Salah satunya adalah aktivitas dalam melakukan transaksi peminjaman dan pengembalian buku serta pengelolaan data-data buku dan data peminjaman buku yang memiliki garis tanggung jawab kepada pegawai perpustakaan sekolah. Selama ini sistemnya masih menerapkan sistem basis data manual, semua proses transaksi peminjaman dan pengembalian buku, pengelolaan data buku serta laporan data buku ditulis manual pada kertas. Tentu saja penggunaan sistem basis data manual tersebut dalam pengaksesan data atau informasinya akan lambat, kurang efisien bahkan data atau informasi belum tentu terjamin akurasinya. Hal ini diperoleh dari hasil pengamatan dan wawancara penulis dengan ketua perpustakaan dan juga petugas perpustakaan di sekolah SMAN 1 BAYAN.

Berdasarkan uraian dan analisa yang telah dilakukan, maka penulis menyimpulkan bahwa solusi yang dapat ditawarkan yaitu pembuatan "Sistem Informasi Perpustakaan SMAN 1 BAYAN Berbasis Website dengan PHP 
MYSQL". Dengan adanya sistem informasi ini diharapkan dapat membantu petugas perpustakaan sekolah SMAN 1 BAYAN dalam memberikan pelayanan transaksi peminjaman dan pengembalian buku kepada anggotanya serta mempermudah dalam melakukan pengelolaan laporan data buku dan data peminjaman buku.

\section{TINJAUAN PUSTAKA}

\subsection{Penelitian Terkait}

Sebagai bahan referensi untuk membantu dalam pembuatan sistem informasi perpustakaan ini, maka terdapat beberapa penelitian dan buku, serta jurnal yang terkait dengan penelitian ini, diantaranya:

a. Pembuatan Sistem Informasi Perpustakaan Berbasis Website Pada Sekolah Menengah Pertama Negeri 1 Donorojo Kabupaten Pacitan, oleh Dani Eko Hendrianto, pada tahun 2014. Hasil penelitiannya dapat meningkatkan pelayanan dan kinerja petugas perpustakaan dalam hal pengelolaan data administrasi perpustakaan serta mempercepat transaksi peminjaman dan pengembalian buku oleh siswa[2].

b. Penelitian Rancang Bangun Sistem Informasi Perpustakaan Pada Sekolah SMK Yadika 13 Tambun Utara Berbasis $W e b$. Sistem yang dibangun dapat membantu staf perpustakaan Sekolah SMK Yadika 13 Tambun Utara dalam mengelola data-data buku, penyusunan laporan secara cepat dan tepat, serta dapat membantu mempermudah siswa dalam mencari buku yang dibutuhkan[3].

c. Sistem Informasi Perpustakaan Umum Grati Kabupaten Pasuruan Berbasis Web Menggunakan Program PHP dan Database MYSQL, oleh Herman Adi Riyanto, Sadikin, dan M. Roziq Zanuddin pada tahun 2016, hasil penelitian ini dapat memberikan solusi mempermudah dan mempercepat proses peminjaman dan pengembalian buku serta mempermudah dalam membuat laporan data buku dan data peminjaman buku secara komputerisasi[1].

\subsection{Sistem Informasi}

Sistem informasi dapat diartikan sebagai sekumpulan elemen yang bekerja secara bersama-sama baik secara manual ataupun berbasis komputer dalam melaksanakan pengolahan data yang berupa pengumpulan, penyimpanan, pemrosesan data untuk menghasilkan informasi yang bermakna dan berguna bagi proses pengambilan keputusan pada berbagai tingkatan manajemen. Berdasarkan definisi tersebut, dapat disimpulkan bahwa sistem informasi merupakan data yang dikumpulkan, dikelompokkan dan diolah sedemikian rupa sehingga menjadi sebuah satu kesatuan informasi yang saling dan saling mendukung sehingga menjadi informasi yang berharga bagi yang menerimanya[4].

\subsection{Database}

Basis data (database) merupakan kumpulan dari data yang saling berhubungan satu dengan lainnya, tersimpan di perangkat keras komputer dan digunakan perangkat lunak untuk memanipulasinya. Sebuah basis data adalah tempat penyimpanan file data. Sebagai file data, suatu basis data tidak dapat menyajikan informasi secara langsung kepada pengguna. Pengguna harus menjalankan aplikasi untuk mengakses data dari basis data dan menyajikannya dalam bentuk yang bisa dimengerti[5].

\subsection{ERD (Entity Relationship Diagram)}

Entity Relationship Diagram (ERD) adalah diagram yang menjelaskan data dan objek. Deskripsi ini disebut entitas yang diambil berdasarkan dari objek dunia nyata serta relasi antar entitas dengan penggunaan beberapa notasi standar. Tahap ini bertujuan mengintegrasikan data dalam basis data[6].

\subsection{Use Case Diagram}

Use case diagram (use case) merupakan pemodelan untuk kelakuan sistem informasi yang akan dibuat. Use case mendeskripsikan sebuah interaksi antara satu atau lebih actor dengan sistem informasi yang akan dibuat. Secara kasar use case digunakan untuk mengetahui fungsi apa saja yang ada didalam sebuah sistem informasi dan siapa saja yang berhak menggunakan fungsi-fungsi itu[7].

\subsection{Activity Diagram}

Activity diagram menggambarkan berbagai alir aktivitas dalam sistem yang sedang dirancang, bagaimana masing-masing alir berawal, decision yang mungkin terjadi, dan bagaimana mereka berakhir. Activity diagram yang menggambarkan logika prosedural, proses bisnis, alur kerja atau aktivitas, dan skenario dalam sebuah proses[7] 


\subsection{Aplikasi Berbasis Web}

Website atau situs dapat diartikan sebagai kumpulan halaman-halaman yang digunakan untuk menampilkan informasi teks, gambar diam atau gerak, animasi, suara, dan atau gabungan dari semuanya baik yang bersifat statis maupun dinamis yang membentuk satu rangkaian bangunan yang saling terkait, yang masing-masing dihubungkan dengan jaringan-jaringan halaman. Hubungan antara satu halaman web dengan halaman web yang lainnya disebut hyperlink, sedangkan teks yang dijadikan media penghubung disebut hypetext[8].

\subsection{PHP}

PHP merupakan suatu bahasa pemrograman yang difungsikan untuk membangun suatu website dinamis. PHP berjalan pada sisi server, sehingga PHP di sebut juga sebagai bahasa Server Side Scripring, artinya bahwa dalam setiap menjalankan PHP, wajib membutuhkan web server dalam menjalankannya[7].

\subsection{MySQL}

My Structured Query Language (MySQL) adalah salah satu database popular dan mendunia. Intinya MySQL bekerja menggunakan SQL Language (Structure Query Language), itu dapat diartikan bahwa MySQL merupakan standar penggunaan database di dunia untuk pengolahan data][7].

\subsection{Sublime Text 3}

Sublime text adalah text editor berbasis Python, sebuah text editor yang elegan, kaya fitur, cross platform, mudah dan simple yang cukup terkenal dikalangan developer (pengembang) dan desainer. Sublime Text 3 digunakan sebagai editor dari bahasa pemrograman PHP dalam melakukan pengelolaan konten di dalam aplikasi server [9]

\section{METODE PENGABDIAN MASYARAKAT}

\subsection{Metode Perancangan Sistem}

Model waterfall digunakan dalam pengembangan sistem ini karena prosesnya yang mengalir secara sistematis dari satu tahap ke tahap yang lain sehingga mudah untuk digunakan dalam pengembangan suatu sistem[10]. Tahapan metode waterfall diantaranya yaitu analisis kebutuhan sistem, desain sistem, implementasi, testing dan maintenance. Tahap pertama yaitu data-data tentang administrasi perpustakaan SMAN 1 BAYAN dan keinginan dari client didata dan dianalisa, kemudian hasil dari analisa tersebut dijadikan dasar untuk melakaukan desain aplikasi meliputi desain interface dan database. Setelah desain aplikasi didapatkan maka tahap selanjutnya dilakukan proses implementasi desain kedalam bahasa pemrograman. Setelah tahap coding selesai maka sistem dapat diuji. Setelah semua tahap selesai maka yang perlu dilakukan perawatan sistem. Alur kerja dari metode waterfall dapat dilihat pada Gambar 1.

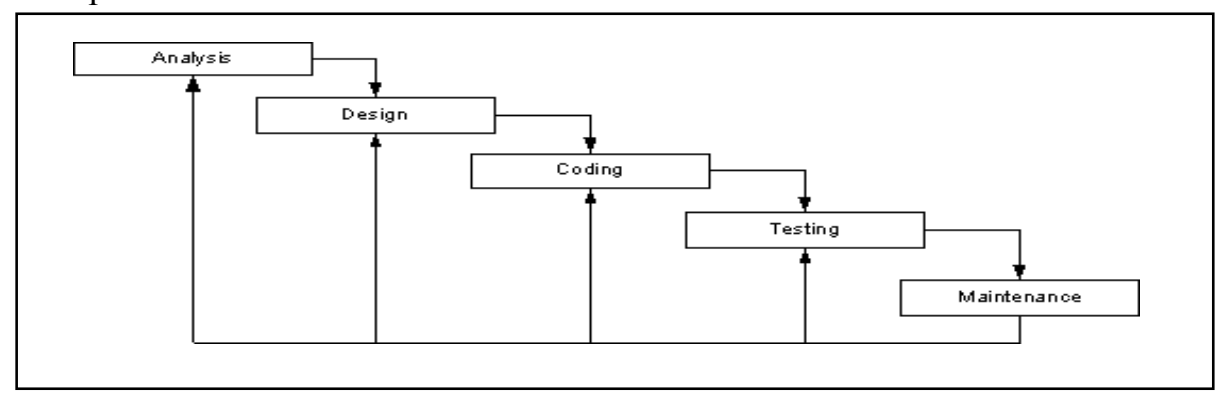

Gambar 1. Metode penelitian waterfall 


\subsection{Desain Sistem}

Tahap perancangan Sistem Informasi Perpustakaan SMAN 1 BAYAN ini menggunakan tiga diagram UML seperti yang telah dijelaskan sebelumnya, yang terdiri dari use case, activity, serta ERD.

\subsubsection{Use Case Diagram}

Berikut ini merupakan Use Case Digaram dari Sistem Informasi Perpustakaan SMAN 1 BAYAN, Kecamatan Bayan, Lombok Utara, Nusa Tenggara Barat yang ditunjukan pada gambar 2.

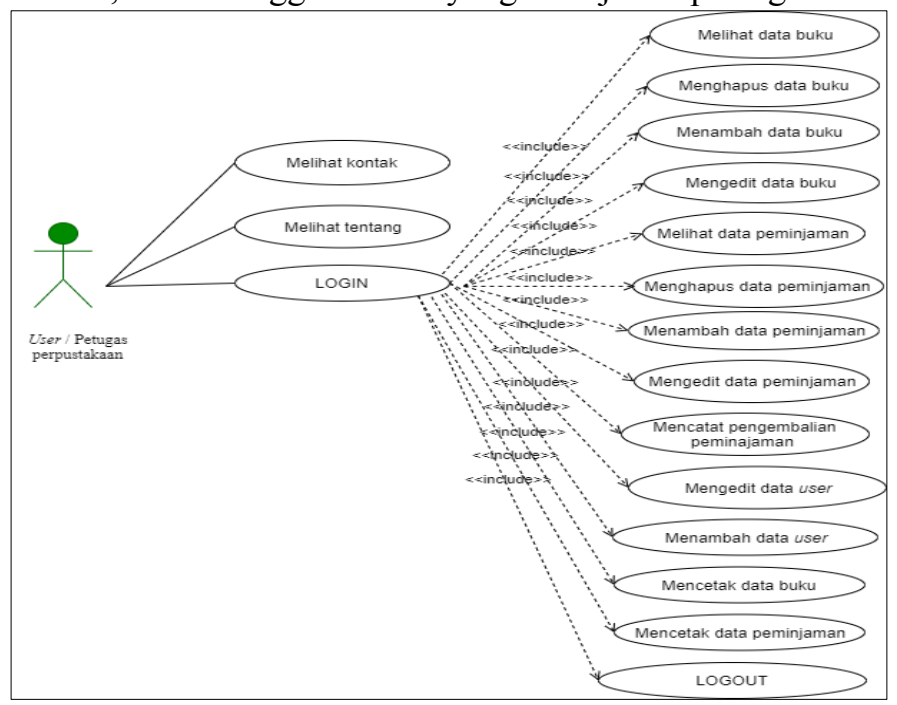

Gambar 2. Use case diagram

Diagram di atas menunjukkan bahwa ada satu aktor yang dapat menggunakan sistem ini, yaitu user atau petugas perpustakaan. Adapun rincian fitur-fiturnya yakni sebagai berikut, Melihat contact, Melihat about, Login, Melihat data buku, Menghapus data buku, Menambah data buku, Mengedit data buku, Melihat data peminjaman, Menghapus data peminjaman, Menambah data peminjaman, Mengedit data peminjaman, Mencatat pengembalian peminjaman, Menambah data user, Mencetak data buku, Mencetak data peminjaman, dan Logout.

\subsubsection{Activity Diagram}

Berikut merupakan beberapa Activity diagram dari Sistem Informasi Perpustakaan SMAN 1 BAYAN.

a. $\quad$ Proses Login User atau Petugas Perpustakaan

Diagram aktivitas di bawah menggambarkan aktivitas untuk mesuk ke dalam sistem melalui proses login yang dilakukan oleh user. Ketika pertama kali diakses, sistem akan menampilkan form login yang harus diisi oleh user, dimana user harus meng-input-kan username dan password sesuai dengan data yang telah terdaftar pada database sistem.

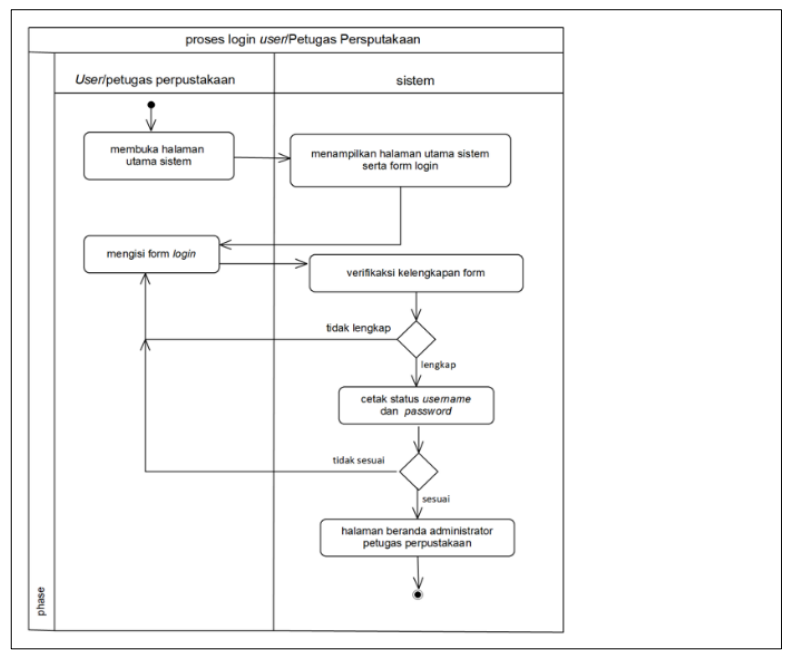

Gambar 3. Proses login user 
b. Proses menambah data buku

Diagram aktivitas di bawah menggambarkan aktivitas ketika user menambah data buku. Ketika user mengakses halaman tersebut maka terlebih dahulu user membuka halaman tambah data buku kemudian sistem akan menampilkan form tambah data buku, setelah user mengisi form tambah data buku sistem akan melakukan verifikasi kelengkapan data, jika datanya yang dimasukan oleh user lengkap maka data buku akan disimpan pada database tabel buku, sebaliknya jika data tidak lengkap maka sistem akan mengarahkan petugas perpustakaan kembali ke halaman form tambah data buku.

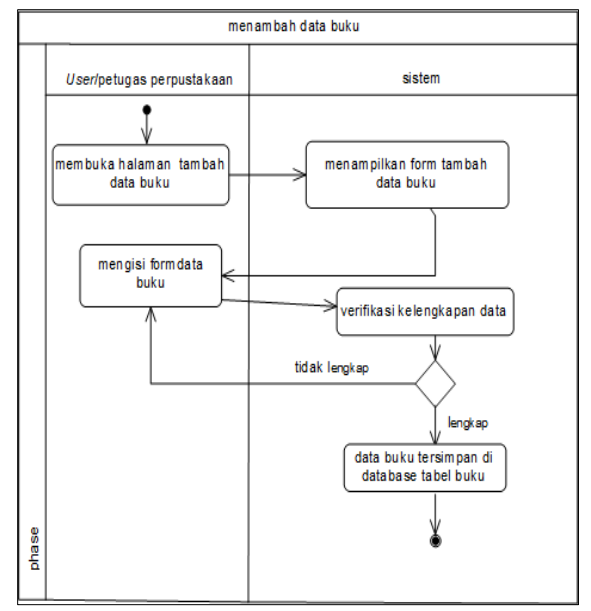

Gambar 4. Proses menambah data buku

c. Proses menambah data peminjaman

Diagram aktivitas di bawah menggambarkan aktivitas ketika user menambah data peminjaman. Ketika user mengakses halaman tambah data peminjaman sistem akan menampilkan form tambah data peminjamaan, setelah petugas perpustakaan mengisi form tambah data peminjaman sistem akan melakukan verifikasi kelengkapan data, jika datanya yang dimasukan oleh petugas perpustakaan lengkap maka data peminjamanakan disimpan pada database di tabel transaksi sebaliknya jika data tidak lengkap maka sistem akan mengarahkan petugas perpustakaan kembali ke halaman form tambah data peminjaman.

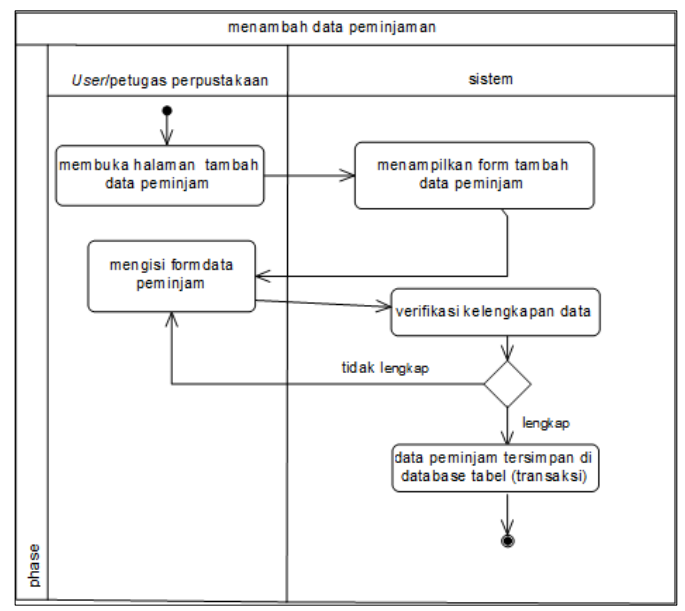

Gambar 5. Proses menambah data peminjaman

d. Proses mencatat pengembalian peminjaman

Diagram aktivitas di bawah menggambarkan aktivitas ketika user mencatat pengembalian peminjaman. Terlebih dahulu user harus membuka halaman pengembalian peminjaman buku seteleh itu sistem akan menampilkan form untuk pengembalian peminjaman buku, selanjutnya user mengisi form pengembalian buku, kemudian sistem akan menyimpan data pengembalian buku pada database tepatnya di tabel transaksi. 


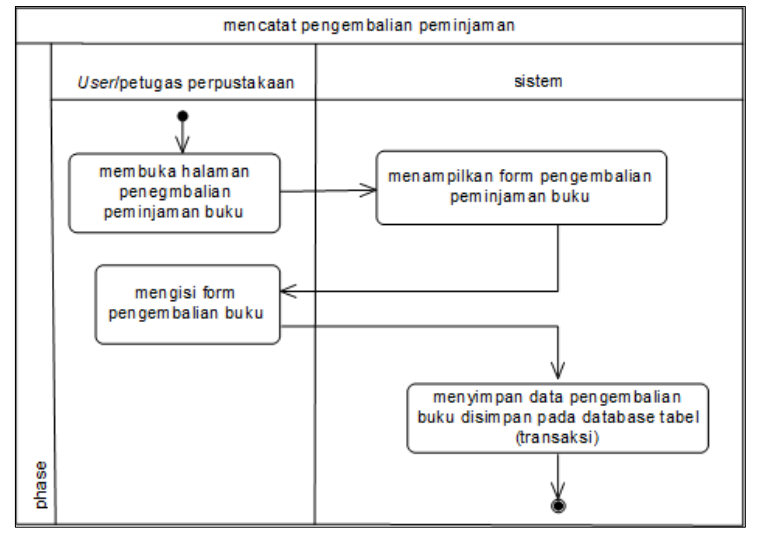

Gambar 6. Proses mencatat pengembalian peminjaman

e. Proses meng-update data user

Diagram aktivitas di bawah menggambarkan aktivitas ketika user mengedit data user. Sistem akan menampilkan form untuk edit data user, setelah user mengisi form sistem akan memverifikasi kelengkapan data. Jika data yang di input-kan oleh user lengkap maka data user tersebut akan di simpan pada database di tabel user sebaliknya jika data tidak lengkap, maka sistem akan mengarahkan user kembali ke halaman form edit data user.

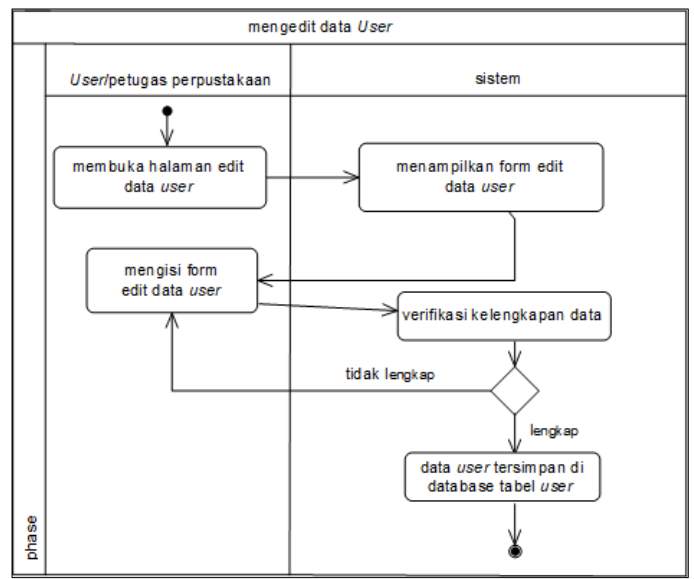

Gambar 7. Proses meng-update data user

f. Proses mencetak laporan data peminjaman

Diagram aktivitas di bawah menggambarkan aktivitas ketika user mencetak laporan data peminjaman buku. Ketika user mengakses halaman tersebut maka terlebih dahulu user membuka halaman laporan data peminjaman, selanjutnya user mengakses cetak laporan data peminjaman dengan mem-filter data peminjaman berdasarkan tanggal pinjam, dengan mencetak semua data peminjaman atau data peminjaman perbulan atau pertahun, dimana jika tidak ada data maka sistem akan menampilkan halaman laporan tanpa data sedangkan jika ada datanya maka sistem akan menampilkan laporan data peminjaman sesuai yang diinginkan oleh user, selanjutnya user bisa langsung mencetak laporan atau menyimpan laporan data peminjaman dalam bentuk pdf. 


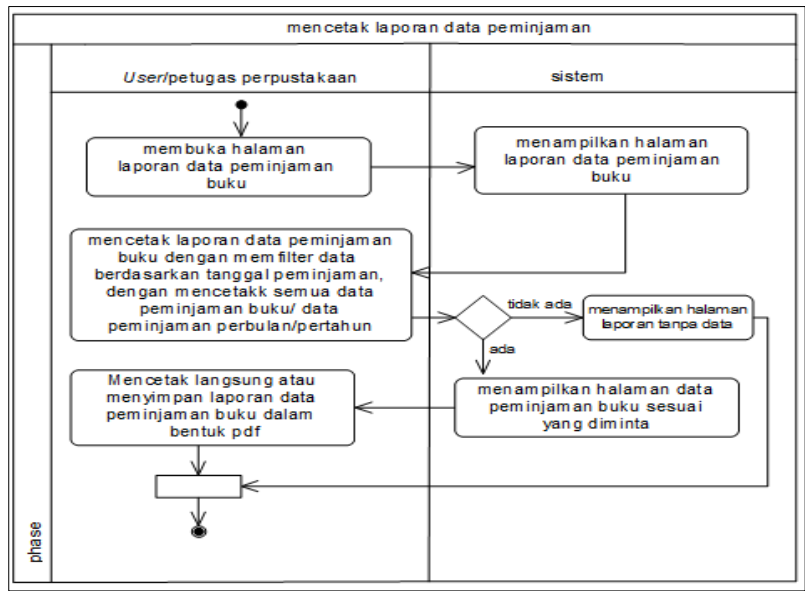

Gambar 8. Proses mencetak laporan data peminjaman

\subsubsection{Entity Relationship Diagram (ERD)}

Pada Gambar di bawah ini adalah ERD (Entity Relationship Diagram) dari Sistem Informasi Perpustakaan SMAN 1 BAYAN.

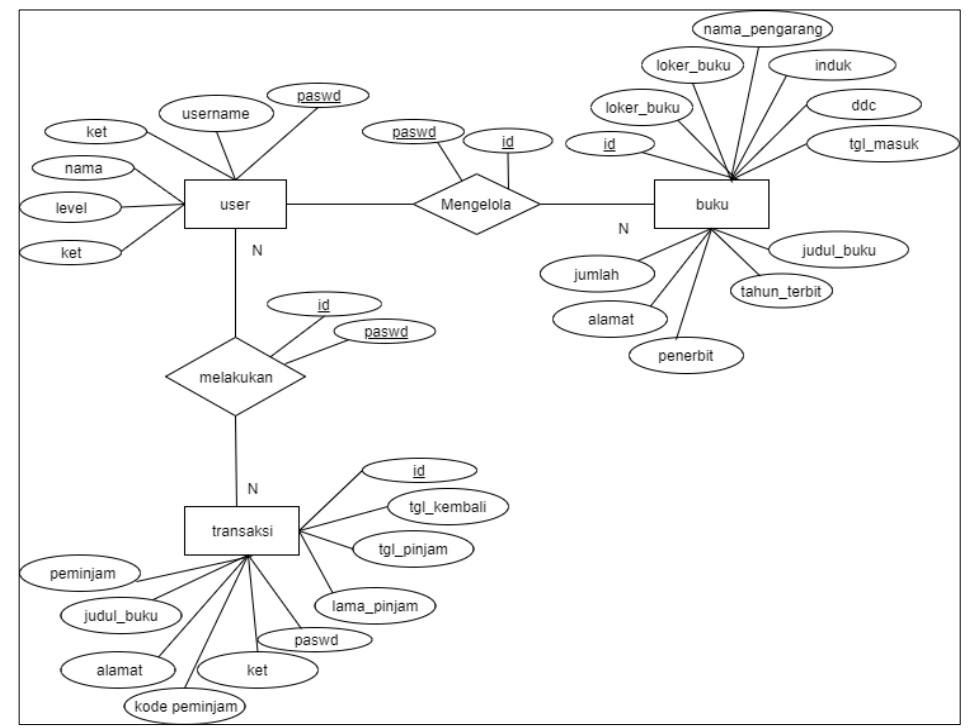

Gambar 9. ERD sistem informasi perpustakaan SMAN 1 BAYAN

\section{HASIL DAN PEMBAHASAN}

\subsection{Implementasi Sistem} BAYAN.

Berikut adalah implementasi tampilan (interface) program dari Sistem Informasi Perpustakaan SMAN 1

a. Halaman Login user

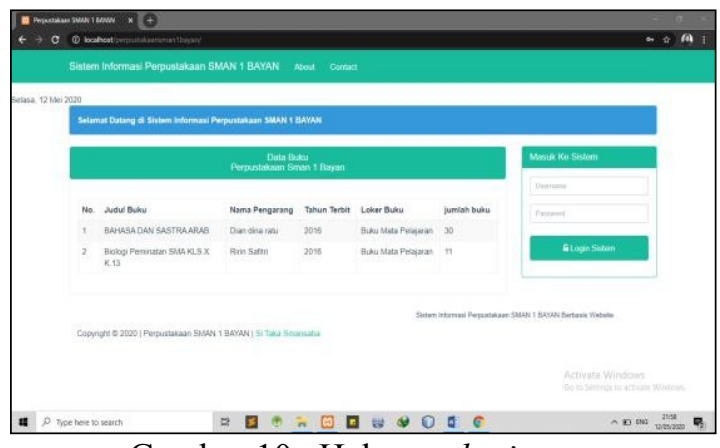

Gambar 10. Halaman login user 
Pada Gambar 10 yang ada di atas merupakan implementasi dari halaman login untuk user atau petugas perpustakaan, halaman ini yang muncul pertama kali ketika pengguna mengakses sistem informasi ini, user diminnta untuk memasukan username dan password.

b. Halaman tampilan data buku

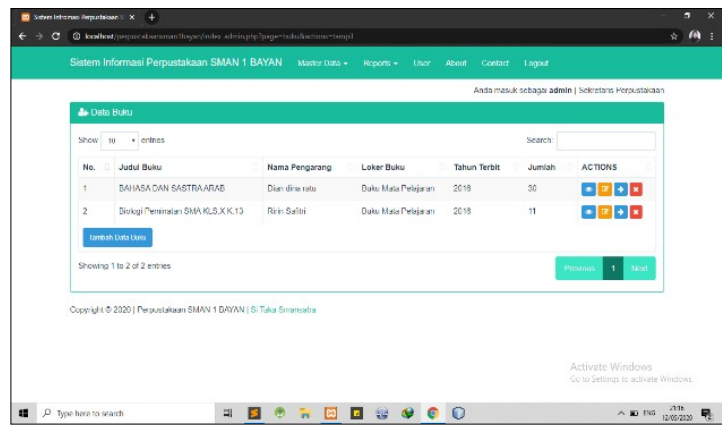

Gambar 11. Halaman tampilan data buku

Pada Gambar 11 yang ada di atas merupakan implementasi dari halaman tampilan data buku, tampilan ini akan muncul ketika user mengakses fitur daftar buku.

c. Halaman tambah data buku

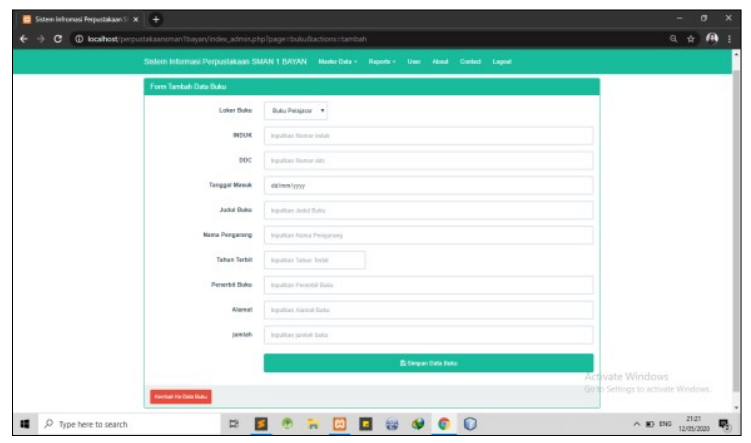

Gambar 12. Halaman tambah data buku

Pada Gambar 12 merupakan implementasi dari halaman tambah data buku yang digunakan oleh user atau petugas perpustakaan untuk meng-input data-data buku perpustakaan sekolah SMAN 1 BAYAN. d. Halaman tambah data peminjaman buku

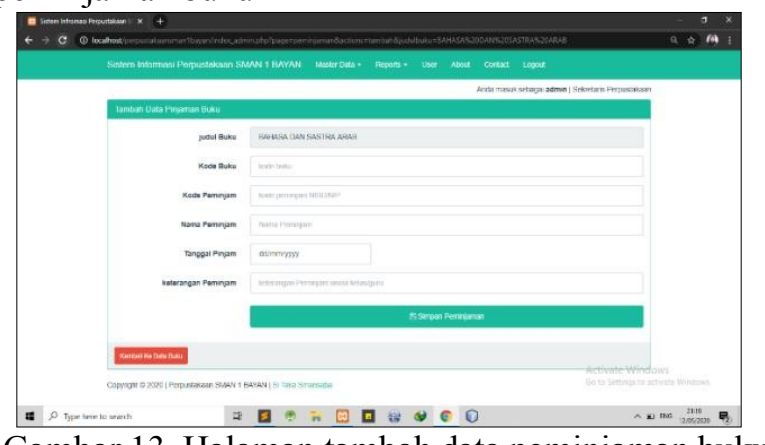

Gambar 13. Halaman tambah data peminjaman buku.

Pada Gambar 13 merupakan implementasi dari halaman tambah data peminjaman buku, dimana halaman ini digunakan oleh user untuk menambah data peminjaman buku ketika anggota perpustakaan meminjam buku. 
e. Halaman tampilan data peminjaman

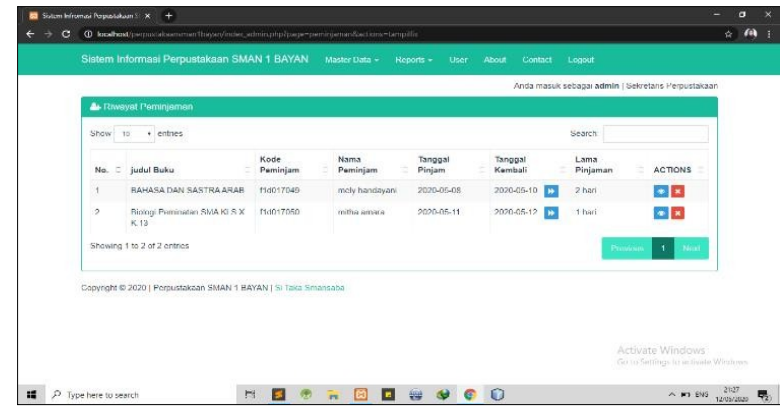

Gambar 14. Halaman tampilan data peminjaman

Pada Gambar 14 merupakan implementasi dari halaman tampilan data buku, halaman ini akanmuncul ketika user mengakses fitur data peminjaman.

f. Halaman pengembalian peminjaman buku

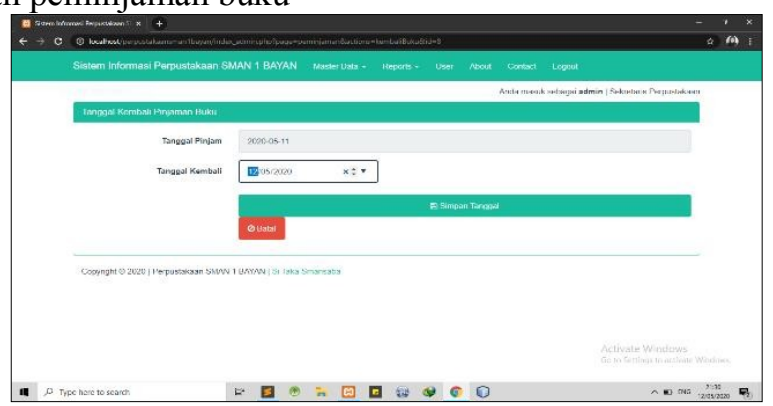

Gambar 15. Halaman pengembalian peminjaman data buku

Gambar 15 di atas merupakan tampilan ketika user atau petugas perpustakaaan hendak melakukan pengembalian peminjaman buku. User harus memasukan tanggal pengembalian peminjaman. Pada bagain bawah terdapat tombol batal jika tidak jadi melakukan proses pengembalian peminjman buku.

g. Halaman tampilan data user

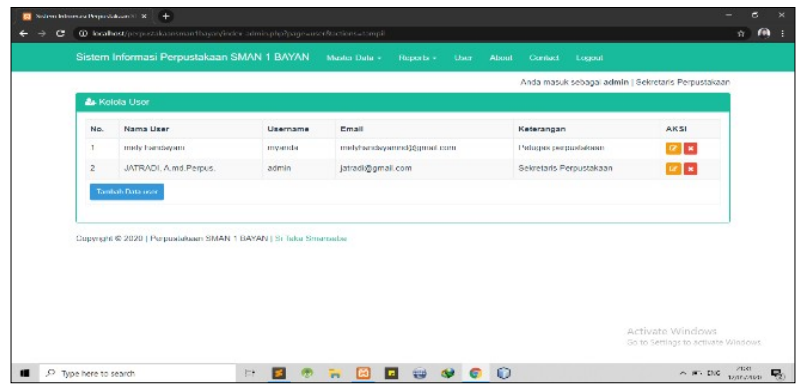

Gambar 16. Halaman tampilan data user

Pada Gambar 16 merupakan implementasi dari halaman data user, dimana halaman ini akan menampilkan data user atau petugas perpustakaan.

h. Halaman tampilan laporan data buku

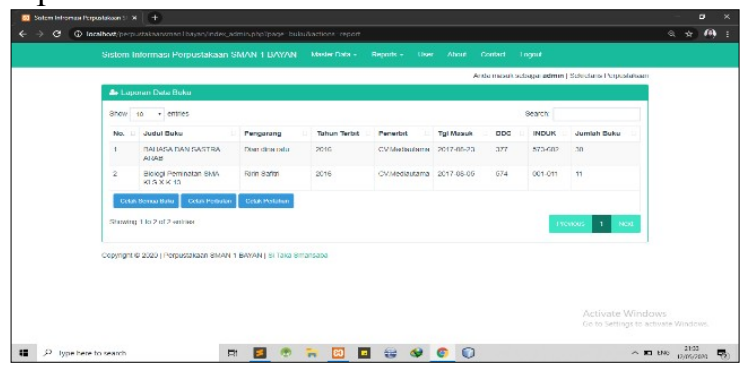

Gambar 17. Halaman tampilan laporan data buku

Pada Gambar 17 merupakan implementasi dari halaman tampilan laporan data buku, tampilan iniyang menampilkan halaman laporan data buku. Adapun data yang ditampilkan meliputi judul buku, pengarang, tahun terbit, penerbit, tanggal masuk, DDC, INDUK, dan jumlah buku. Pada bagian 
kiri bawah tabel laporan data buku terdapat tiga tombol yakni ada untuk mencetak semua data buku, cetak data buku perbulan, dan cetak buku petahun.

i. Halaman laporan data peminjaman buku

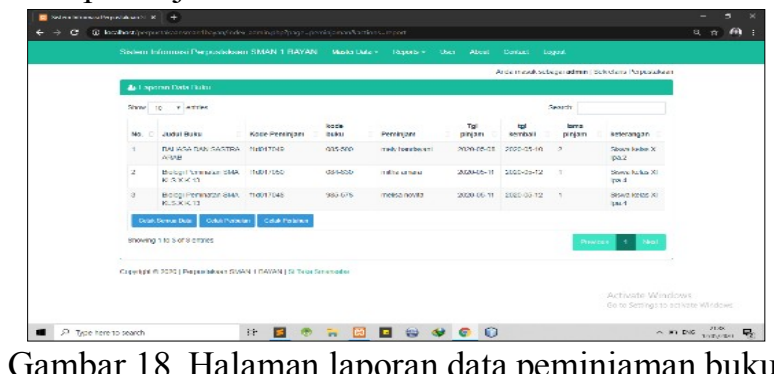

Pada Gambar 18 merupakan implementasi dari halaman laporan data peminjaman buku, adapun data yang ditampilkan meliputi judul buku, kode peminjam, kode buku, nama peminjam, tanggal pinjam, tanggal kembali, lama pinjam, dan keterangan. Pada bagian kiri bawah tabel laporan data peminjaman buku terdapat tiga tombol yakni ada untuk mencetak semua data peminjaman buku, cetak data peminjaman buku perbulan, dan cetak peminjaman buku petahun.

j. Halaman tampilan mencetak laporan data peminjaman buku perbulan

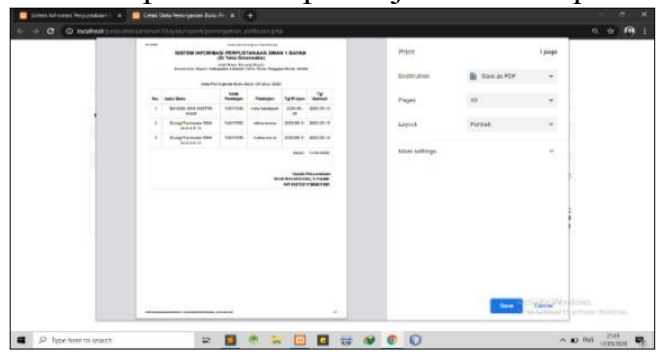

Gambar 19. Halaman laporan data peminjaman buku perbulan

Pada Gambar 19 merupakan implementasi dari halaman mencetak laporan data peminjaman buku perbulan pada sistem.

\subsection{Pengujian Kuesioner}

Setelah dilakukan pengimplementasian sistem selanjutnya dilakukan pengujian sistem. Pengujian dengan menggunakan kuesioner dilakukan dengan cara mencari responden yang merupakan user dari sistem ini yakni para petugas perpustakaan sekolah SMAN 1 BAYAN, untuk melakukan uji coba sistem dan menjawab pernyataan pada kuesioner yang diberikan. Parameter pengujian yang digunakan pada metode ini adalah sebagai berikut:

a. Tampilan sistem sudah sangat baik dan mudah di gunakan.

b. Sistem mempermudah pekerjaan petugas perpustakaan.

c. Sistem peminjaman dan pengembalian buku sudah akurat.

d. Sistem sudah menghasilkan laporan data buku dan data peminjaman buku yang akurat.

e. Sistem sangat menunjng kinerja instansi.

Responden akan diberikan pilihan jawaban dari pertanyaan-pertanyaan di atas, yaitu:

a. $\mathrm{SS}=$ Sangat Setuju

b. $\mathrm{S}=$ Setuju

c. $\mathrm{BS}=$ Biasa Saja

d. $\quad$ TS $=$ Tidak Setuju

e. $\quad$ STS = Sangat Tidak Setuju

Hasil rekapitulasi jawaban responden dihitung dari jawaban berdasarkan pengisian kuesioner dari masingmasing pernyataan. Berikut pada tabel 1 merupakan persentase jawaban rata-rata hasil pengujian dari 5 responden. 
Tabel 1. Persentase hasil pengujian sistem

\begin{tabular}{|c|c|c|c|c|c|c|}
\hline \multirow[t]{2}{*}{ No } & \multirow[t]{2}{*}{ Pernyataan } & \multicolumn{5}{|c|}{ Jawaban } \\
\hline & & SS & $\mathbf{S}$ & BS & TS & STS \\
\hline 1 & Tampilan sistem sudah sangat baik dan mudah digunakan. & 3 & 2 & 0 & 0 & 0 \\
\hline 2 & Sistem mempermudah pekerjaan petugas perpustakaan. & 4 & 1 & 0 & 0 & 0 \\
\hline 3 & Sistem peminjaman dan pengembalian buku sudah akurat. & 4 & 1 & 0 & 0 & 0 \\
\hline 4 & $\begin{array}{l}\text { Sistem sudah menghasilkan laporan data buku dan data peminjaman } \\
\text { buku yang akurat. }\end{array}$ & 4 & 1 & 0 & 0 & 0 \\
\hline \multirow[t]{4}{*}{5} & Sistem sangat menunjng kinerja instansi. & 3 & 2 & 0 & 0 & 0 \\
\hline & Total & 18 & 7 & $\mathbf{0}$ & $\mathbf{0}$ & $\mathbf{0}$ \\
\hline & Rata - Rata & 0.72 & 0.28 & $\mathbf{0}$ & $\mathbf{0}$ & $\mathbf{0}$ \\
\hline & Persentase & $72 \%$ & $28 \%$ & & & \\
\hline
\end{tabular}

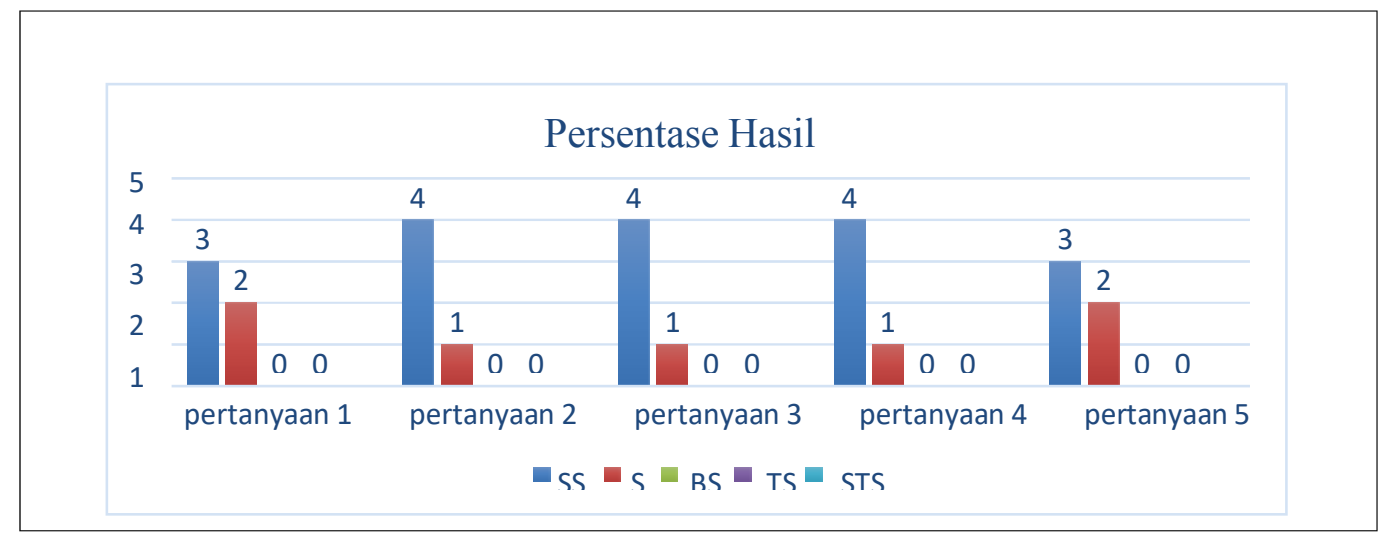

Gambar 20. Grafik persentase hasil pengujian

Pada Gambar 20 merupakan hasil dari persentase pengujian dari kuesioner yang diberikan mendapatkan nilai untuk pernyataan 1 nilai Sangat Setuju dan Setuju masing-masing diberikan oleh 3 dan 2 responden, pernyataan 2 nilai Sangat Setuju dan Setuju masing-masing diberikan oleh 4 dan 1 responden, pernyataan 3 nilai Sangat Setuju dan Setuju masing-masing diberikan oleh 4 dan 1 responden, pernyataan 4 nilai Sangat Setuju dan Setuju masing-masing diberikan oleh 4 dan 1 responden, dan pernyataan 5 nilai Sangat Setuju dan Setuju masingmasing diberikan oleh 3 dan 2 responden. Dilihat dari tabel persentase hasil pengujian didapatkanpersentase hasil jawaban sangat setuju sebesar $72 \%$ dan setuju sebesar $28 \%$. Jadi, Berdasarkan persentase hasil pengujian sistem tersebut responden setuju dengan sistem ini, serta sistem ini juga sudah terimplementasi dengan baik.

\subsection{Dokumentasi Penggunaan Sistem}

Berikut merupakan dokumentasi penggunaan sistem informasi perpustakaan SMAN 1 BAYAN oleh salah satu user atau Petugas perpustakaan SMAN 1 BAYAN sambil melakukan pengisian kuesioner uji manfaat sistem perpustakaan SMAN 1 BAYAN berbasis website yang telah dibangun.

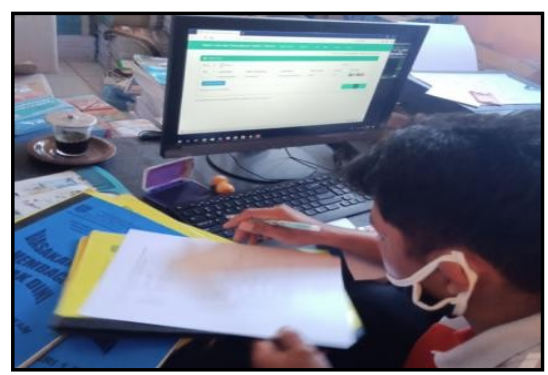

Gambar 21. Penggunaan sistem oleh user 


\section{KESIMPULAN DAN SARAN}

\subsection{Kesimpulan}

Berdasarkan hasil pengabdian masyarakat di SMAN 1 BAYAN berupa Sistem Informasi Perpustakaan SMAN 1 BAYAN berbasis web dengan PHP MYSQL, maka didapatkan kesimpulan sebagai berikut:

a. Rancangan Sistem Informasi Perpustakaan SMAN 1 BAYAN berbasis web dibuat berdasarkan dari hasil analisa terhadap kebutuhan serta kinerja dari instansi terkait untuk menghasilkan sistem sesuai kebutuhan.

b. Sistem informasi perpustakaan SMAN 1 BAYAN berbasis web yang dibangun menyediakan fitur melihat contact, melihat tentang, Login ke sistem, melihat data buku, menghapus data buku, menambah data buku, mengedit data buku, melihat data peminjaman, menghapus data peminjaman, menambah data peminjaman, mengedit data peminajaman, mencatat pengembalian peminjaman, mengedit data user, menambah data user, mencetak data buku, mencetak data peminjaman, dan Logout dari sistem. Sehingga dapat mempermudah petugas perpustakaan sekolah SMAN 1 BAYAN dalam memberikan pelayanan transaksi peminjaman dan pengembalian buku kepada anggotanya serta mempermudah dalam proses pengelolaan laporan data buku dan laporan data peminjaman buku.

c. Sistem Informasi perpustakaan yang dibangun sudah terimplementasi dengan baik, berdasarkan hasil pengujian kuesioner didapatkan bahwa persentase hasil jawaban user sangat setuju yaitu sebesar $72 \%$ dan jawaban setuju sebesar $28 \%$.

\subsection{Saran}

Saran yang dapat diberikan penulis agar Sistem Informasi Perpustakaan SMAN 1 BAYAN berbasis web ini menjadi lebih baik di masa yang akan datang, perlunya dilakukan analisa dan perancangan lebih mendalam terhadap kinerja instansi untuk membangun sebuah sistem yang sesuai dengan kebutuhan instansi dalam waktu yang singkat. Serta diharapkan agar Sistem Informasi Perpustakaan SMAN 1 BAYAN ini dapat dikembangkan lagi dalam hal tampilan, terutama fitur-fitur serta fungsinya agar dapat dimanfaatkan lebih maksimal.

\section{DAFTAR PUSTAKA}

[1] H. A. Riyanto, Sadikin, and M. R. Zanuddin, "Sistem Informasi Perpustakaan Umum Grati Kabupaten Pasuruan Berbasis Web Menggunakan Program Php Dan Database Mysql," J I M P - J. Inform. Merdeka Pasuruan, vol. 1, no. 2, pp. 1-14, 2016, doi: 10.37438/jimp.v1i2.13.

[2] D. E. Hendrianto, "Pembuatan Sistem Informasi Perpustakaan Berbasis Website Pada Sekolah Menegah Pertama Negeri 1 Donorojo Kabupaten Pacitan," Indones. J. Netw. Secur., vol. 3, no. 4, pp. 57-64, 2014.

[3] D. Pratiwi, S. Hartini, and S. Marlina, "Rancang Bangun Sistem Informasi Perpustakaan Pada Sekolah SMK Yadika 13 Tambun Utara Berbasis Web," vol. XX, no. 1, pp. 53-58, 2018.

[4] Y. Heriyanto, "Perancangan Sistem Informasi Rental Mobil Berbasis Web Pada PT.APM Rent Car," J. IntraTech, vol. 2, no. 2, pp. 64-77, 2018.

[5] M. A. Suripto and R. A. Triyono, "Pembangunan Sistem Informasi Akta Kelahiran," Indones. J. Netw. Secur., vol. 3, no. 3, pp. 33-40, 2014, [Online]. Available: http://ijns.org/journal/index.php/ijns/article/view/403.

[6] Mustianti, I. B. K. Widiartha, and M. A. Albar, "Sistem Informasi Tugas Akhir Program Studi Informatika," J. Teknol. Informasi, Komputer, dan Apl. (JTIKA ), vol. 2, no. 1, pp. 19-29, 2020, doi: 10.29303/jtika.v2i1.43.

[7] H. Irsyad, "Penerapan Metode Waterfall Pada Aplikasi Perumahan Di Kota Palembang Berbasis Web Mobile (Studi Kasus Pt. Sandaran Sukses Abadi),"J. Tek. Inform. Musirawas, vol. 3, no. 1, p. 9, 2018, doi: 10.32767/jutim.v3i1.310.

[8] F. A. Batubara, "Perancangan Website Pada Pt . Ratu Enim Palembang," pp. 15-27, 2012.

[9] D. Pradiatiningtyas and Suparwanto, "E-Learning Sebagai Media Pembelajaran Berbasis Web Pada Smk N 4 Purworejo," Indones. J. Netw. Secur., vol. 7, no. 2, pp. 1-8, 2017, [Online]. Available: https://ijns.org/journal/index.php/ijns/article/download/1499/1460.

[10] I. B. K. Widiartha, N. M. Puspitayanti, and S. E. Anjarwani, "Rancang Bangun Sistem Informasi Akreditasi Sekolah," J. Teknol. Informasi, Komputer, dan Apl. (JTIKA ), vol. 1, no. 1, pp. 41-48, 2019, doi: 10.29303/jtika.vli1.18. 